\title{
Determination of Di(2-ethylhexyl phthalate) released in the blood from PVC line during the hemodialysis procedure
}

\author{
Determinação de Di(2-etilhexil ftalato) liberado \\ no sangue por linhas de PVC durante 0 \\ procedimento de hemodiálise
}

\author{
Beatriz Luci Fernandes ${ }^{1}$, Fernanda Maria ${ }^{1}$, Lia Sumie Nakao ${ }^{2}$. \\ Max Ingberman ${ }^{2}$, Marcia Regina Cubas ${ }^{1}$
}

\footnotetext{
${ }^{1}$ Programa de Pós Graduação em Tecnologia em Saúde - PPGTS/PUCPR, Rua Imaculada Conceição, 1155, Prado Velho, CEP: 80215-901, Curitiba, PR, Brasil

e-mail: beatriz.fernandes@pucpr.br; fermaria83@hotmail.com; m.cubas@pucpr.br

${ }^{2}$ Departamento de Patologia Básica - Centro Politécnico/UFPR, Av. Coronel Francisco Heráclito dos Santos, 210, Jardim das Américas, Curitiba, PR, Brasil

e-mail:1.nakao@ufpr.br; maxebb@gmail.com
}

\section{RESUMO}

O objetivo deste trabalho é demonstrar a aplicabilidade da Cromatografia Líquida de Alta Eficiência na quantificação do Di(2-etilhexil ftalato) (DEHP) liberado pela linha de Policloreto de vinila (PVC) no sangue circulante durante o procedimento de hemodiálise. Como a proposta não é a validação do método foram coletadas amostras de sangue de cinco pacientes voluntários e de três voluntários saudáveis e os plasmas foram isolados, preparados e analisados. A concentração média de DEHP no sangue no plasma dos pacientes foi $0.19 \pm 0.12 \mathrm{mg} / \mathrm{kg}$ de massa corpórea, enquanto que no plasma dos voluntários saudáveis foi $0.003 \pm 0.002$ $\mu \mathrm{g} / \mathrm{kg}$ de massa corpórea. Os resultados mostraram que o método apresentado é uma alternativa para a determinação de DEPH no sangue e que poderá auxiliar na busca por outros materiais para aplicação em equipamentos de circulação extracorpórea. O estudo foi realizado de acordo com os padrões nacionais e internacionais de ética em pesquisa envolvendo seres humanos (CEP PUCPR Prot. n.5802).

Palavras-chave: Diálise renal, Toxicidade crônica, DEHP.

\section{ABSTRACT}

The objective of the work is to demonstrate the applicability of the High-Performance Liquid Chromatography (HPLC) on the quantification of the Di(2-ethylhexyl phthalate) (DEHP) released from the Polyvinyl Chloride (PVC) line into the circulating blood during the hemodialysis procedure. As the proposal is not to validate the method, blood samples from five patients and three healthy volunteers were collected, and the plasmas were isolated, prepared and analyzed. The average concentration of DEHP in the patient's plasma was $0.19 \pm 0.12 \mathrm{mg} / \mathrm{kg}$ of body mass, while in the plasma of the healthy volunteers was $0.003 \pm 0.002 \mu \mathrm{g} / \mathrm{kg}$ of body mass. The results showed that the method presented is an alternative to quantify the DEHP in the blood and could assist in the search for alternative materials to apply to extracorporeal circulation equipment. The study was performed according to the national and international standards of ethics in research involving human beings (CEP PUCPR Prot. n.5802).

Keywords: Renal dialysis, Chronic toxicity, DEHP.

\section{INTRODUCTION}

The Chronic Kidney Disease (CKD) is characterized by a gradual loss of kidney function resulting in increasing of the metabolites concentration in plasma from the protein metabolism. Such a situation causes an increase in urea and creatinine that obligates the patient to undergo long treatment, often leading to chronic complications [1]. The treatments normally used are hemodialysis, peritoneal dialysis and renal transplanta- 
tion [2].

Hemodialysis therapy is carried out through the decontamination of blood during extracorporeal circulation. A pump drives the blood from the patient's body through a dialyzer and returns it to the patient free of toxic substances [3] [4]. In some countries, like Brazil, for now, the extracorporeal circuits can be reused, up to twenty times, on the same patient with the approval of the National Health Surveillance Agency (RDC 154/2004 ANVISA). Although reuse is a normal practice in some hemodialysis centers, it is a controversial subject for many researchers and health professionals, since some studies have shown that reuse has increased the number of hospitalization and mortality [5] [6] [7].

The extracorporeal circuits are made of Polyvinyl Chloride (PVC), one of the most widely used polymers in the medical devices industry [8]. The polymeric chain of PVC is formed from the reaction between vinyl chloride monomers, which polar covalent bonds provide stiffness to the polymer. The plasticizers are added to give flexibility, facilitating the processing and use of the polymer [9] [10].

A quarter of the plasticizers used in the industry corresponds to the di (2-ethylhexyl phthalate) (DEHP) which is present in PVC in up to $40 \%$ by weight, corresponding to about $10 \mathrm{~g}$ of plasticizer in a blood bag [11].The mass diffusion of DEHP from the extracorporeal circuit to the blood depends on several factors including temperature, storage time, blood flow, the percentage of DEHP in the product, and the lipophilic nature of the blood [12]. The DEHP, Figure 1, has a molecular weight of $390.56 \mathrm{~g} / \mathrm{mol}$ [13] and a molecule with low molecular weight $(<1000 \mathrm{~g} / \mathrm{mol})$ have low resistance to cross the membrane of the dialyzer having the concentration gradient as driving force [14]. Also due to its chemical structure and its lipid solubility, DEHP can be easily absorbed by the body [11] [15]. The target organs of DEHP toxicity are kidneys, liver and, in particular, the testicles. Hepatomegaly is related to the DEHP presence as well as platelet aggregation that can cause neurological complications [16].

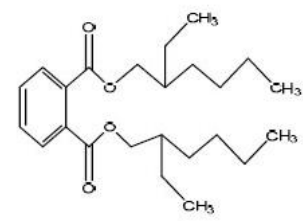

Figura 1: Chemical structure of Di-(2-ethylhexyl) phthalate [17].

Most studies on the effects of DEHP on the body, however, were conducted on animals. Effects in male animals include a change in zinc concentration, infertility, and testicular atrophy. The Food and Drug Administration (FDA) that has reported analogous symptoms in male patients undergoing dialysis, strongly suggesting the similarity between the reactions observed in animals with those observed in humans [18]. Although DEHP contamination is common, most of the works in the literature discuss the contamination associated with industrialized products (pipes and household items) and PVC manufacturing industries. Very few studies are related to the contamination of patients with CKD since most countries have already changed hemodialysis PVC lines by the silicone ones. Brazil, however, continues to use and reuse the PVC lines.

Various analytical methods are available for determination of DEHP in biological systems. Among them, the method considered more accurate, fast and economical is the High-Performance Liquid Chromatography (HPLC). However, the samples are not easily prepared [19], and the few studies using it do not show a clear method able to be reproduced. Therefore, the values found in the literature can hardly be correlated with each other, leading to controversy about the real cumulative effect of DEHP on the body and its clinical implications.

Take into account the importance to quantify the DEHP in the blood to evaluate its systemic effects, the aim of this study is to present a clear procedure to prepare blood samples for HPLC to quantify the DEHP released in the blood of patients during hemodialysis procedures. Also, the purpose is to demonstrate the feasibility of the method. For that, the method of samples preparation, DEHP detection and the mathematical approach are exposed.

\section{MATERIALS AND METHOD}

A prospective primary study was conducted. During the hemodialysis session were collected blood aliquots of $20 \mathrm{ml}$ of five volunteers patients selected by the inclusion criteria: male; above eighteen years of age; diagnosed with CKD; performing hemodialysis therapy from twelve months to twelve years; and hemodialysis sessions of four hours, three times a week. 
The exclusion criteria were: diagnosed with Acquired Immune Deficiency Syndrome (AIDS) and/or hepatitis. For the control group was selected three volunteers considered healthy according to the inclusion criteria: male, over eighteen years with no diagnosed diseases. Because they are considered healthy, there were no exclusion criteria for the control group.

All volunteer patients used the hemodialysis circuit produced by the same manufacturer, including the polyether sulfone dialyzers Nipro ${ }^{\mathrm{TM}}$, model PES-210DL, with a surface area of $2.1 \mathrm{~m}^{2}$, convective clearance and ultrafiltration coefficient of $21 \mathrm{ml} / \mathrm{h} / \mathrm{mmHg}$. All patients underwent the same hemodialysis technique. Were chosen three sessions for each patient volunteer where $10 \mathrm{ml}$ of blood were collected from a peripheral venous, fifteen minutes from the start of the hemodialysis. The aliquot was stored in a heparin tube and immediately centrifuged in an Eppendorf Centrifuge (Model 5702), at $4400 \mathrm{xg}$ for $10 \mathrm{~min}$ to separate the plasma. The plasma was transferred to a glass test tube and frozen to $-80{ }^{\circ} \mathrm{C}$ to prevent DEHP degradation [20], remaining stored until the time of its analysis in the HPLC.

Fifteen minutes before the end of the session a second $10 \mathrm{ml}$ aliquot of blood was collected, also from a peripheral venous. The same procedure for separation of plasma and storage was carried out. The procedures were repeated for the number of reuse of the extracorporeal circuit. The reprocessing of the hemodialysis circuit was performed according to the institution's protocol and by a qualified professional. For the healthy volunteers, it was taken only $10 \mathrm{ml}$ of blood on one occasion. Table 1 shows the hemodialysis parameters for the volunteer patients.

Table 1: Hemodialysis parameters for the volunteer patients.

\begin{tabular}{|c|c|c|c|c|}
\hline $\begin{array}{l}\text { Patient/ } \\
\text { Session }\end{array}$ & $\begin{array}{l}\text { Reuse } \\
\text { number }\end{array}$ & $\begin{array}{l}\text { Heparin dose in the } \\
\text { circuit (UI) }\end{array}$ & Blood flow (ml/min) & $\begin{array}{l}\text { Period of hemodialysis } \\
\text { therapy }\end{array}$ \\
\hline $\mathrm{P} 1 / 1$ & 0 & \multirow{3}{*}{5,000} & \multirow{3}{*}{300} & \multirow{3}{*}{3 years and 3 months } \\
\hline $\mathrm{P} 1 / 2$ & 2 & & & \\
\hline $\mathrm{P} 1 / 3$ & 4 & & & \\
\hline $\mathrm{P} 2 / 1$ & 5 & \multirow{3}{*}{ without heparin* } & \multirow{3}{*}{300} & \multirow{3}{*}{5 years } \\
\hline $\mathrm{P} 2 / 2$ & 7 & & & \\
\hline $\mathrm{P} 2 / 3$ & 9 & & & \\
\hline $\mathrm{P} 3 / 1$ & 9 & \multirow{3}{*}{6,000} & \multirow{3}{*}{300} & \multirow{3}{*}{3 year and 6 months } \\
\hline $\mathrm{P} 3 / 2$ & 11 & & & \\
\hline $\mathrm{P} 3 / 3$ & 13 & & & \\
\hline $\mathrm{P} 4 / 1$ & 0 & \multirow{3}{*}{7,000} & \multirow{3}{*}{350} & \multirow{3}{*}{4 years and 4 months } \\
\hline $\mathrm{P} 4 / 2$ & 2 & & & \\
\hline $\mathrm{P} 4 / 3$ & 4 & & & \\
\hline $\mathrm{P} 5 / 1$ & 11 & \multirow{3}{*}{8,000} & \multirow{3}{*}{350} & \multirow{3}{*}{4 years and 9 months } \\
\hline $\mathrm{P} 5 / 2$ & 13 & & & \\
\hline $\mathrm{P} 5 / 3$ & 15 & & & \\
\hline
\end{tabular}

*Patient candidate for renal transplant. Reuse number 0 means first use.

For the purpose of the study, it was analyzed only the DEHP accumulated in plasma because only a small portion of the plasticizer (between $5 \%$ to 10\%) is associated with the red blood cells [21].

The HPLC analysis was performed by a Shimadzu ${ }^{\mathrm{TM}}$ UV-VIS System LC-20 with the following specifications: column C18 $9(4.6 \times 250 \mathrm{~mm}$ and $5 \mu \mathrm{m}$ particle size $)$ eluted with isocratic system; mobile phase composed of $93 \%$ acetonitrile-sodium octyl sulphate $(10 \mathrm{mM})$, and $7 \%$ of the solution composed of triethanolamine and azide $(0.2 \%: 0.001 \%, \mathrm{v} / \mathrm{v})(\mathrm{pH} 2.5)$ adjusted with orthophosphoric acid; flow rate of 1 $\mathrm{ml} / \mathrm{min}$. The tests were run at $245 \mathrm{~nm}$ wavelength that was previously identified as DEHP standard in UVVIS spectrophotometer NanoDrop ${ }^{\mathrm{TM}}$, Model ND-1000. The retention times were $8 \mathrm{~min}$. Figure 2 presents the chromatogram where the DEHP was detected. 


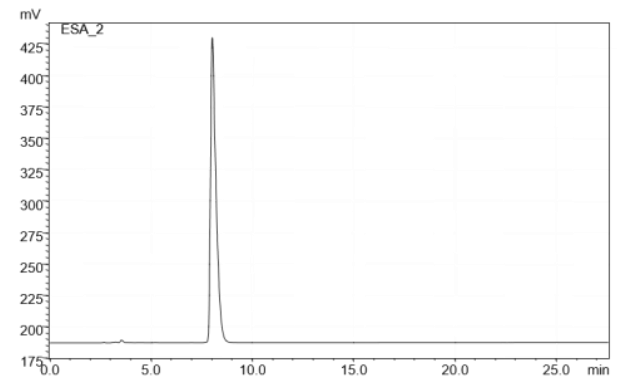

Figura 2: Chromatogram showing the detection or DEPH at a retention time of $8 \mathrm{~min}$.

The calibration curve for the DEHP quantification was constructed using seven samples of plasma from the same healthy volunteers, in which were added $0.000197 \mu \mathrm{g} / \mu \mathrm{l}, 0.000394 \mu \mathrm{g} / \mu \mathrm{l}, 0.000788 \mu \mathrm{g} / \mu \mathrm{l}$, $0.001182 \mu \mathrm{g} / \mu \mathrm{l}, 0.001576 \mu \mathrm{g} / \mu \mathrm{l}, 0.00394 \mu \mathrm{g} / \mu \mathrm{l}$ and $0.00995 \mu \mathrm{g} / \mu \mathrm{l}$, respectively, of the DEHP standard solution diluted with the mobile phase. The DEHP standard solution was purchased from a commercial source (Selectophor ${ }^{\mathrm{TM}}$, Sigma-Aldrich). The calibration curves provided a correlation coefficient $\left(\mathrm{r}^{2}\right)$ always superior to 0.99 , ensuring that the areas under the curves were directly proportional to the analyte concentration.

The plasma samples (two from each patient volunteer) were defrosted until they reached the temperature of $20^{\circ} \mathrm{C}$ to perform the HPLC analysis. The proteins of $250 \mu \mathrm{L}$ of plasma were precipitated with a solution containing $750 \mu \mathrm{l}$ of acetonitrile and $250 \mu \mathrm{l}$ of saturated $\left(\mathrm{NH}_{4}\right)_{2} \mathrm{SO}_{4}$. After mixing in a vortex, the suspensions were centrifuged at $11.336 \mathrm{xg}$ for $20 \mathrm{~min}$ at $4{ }^{\circ} \mathrm{C}$. The supernatant was collected and filtered using a $0.22 \mu \mathrm{m}$ filter (Minisart filter, Sigma-Aldrich). One hundred microliters were eluted with the mobile phase and injected into the HPLC equipment.

The analysis was performed in six days, and a standard curve was generated in each day where a linear regression was applied. The concentration of DEHP was determined by replacing the independent variable " $x$ " in the linear equation by the area under the peak of detection. Figure 3 illustrates the peak detection of DEHP in the patient's blood together with that from the standard DEHP.

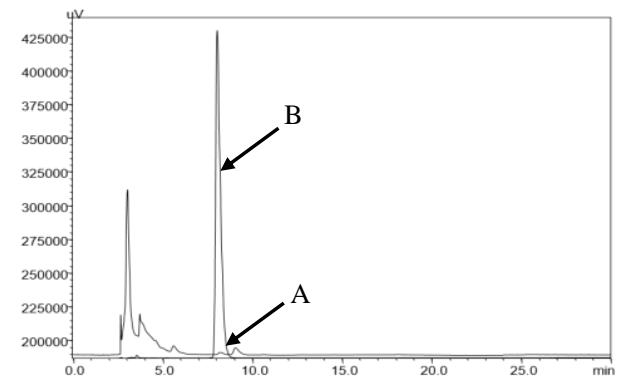

Figura 3: Chromatogram showing the detection of DEPH in the patient's blood (A) and the DEPH standard (B) at a retention time of $8 \mathrm{~min}$.

The non-parametric Kruskal-Wallis test was applied to evaluate if there were differences between the mass of DEHP released per session for different patients, at the 0.05 significance level. The study was performed according to the national and international standards of ethics in research involving human beings (Ethics Committee Protocol PUCPR n. 5802).

\section{RESULTS}

Table 2 shows the results of the linear regression of the curves generated during the HPLC analysis for the volunteer's patients $(\mathrm{P})$ and the healthy volunteers $(\mathrm{V})$. 
Table 2: Linear regression of the curves for each day of analysis.

\begin{tabular}{|c|c|c|c|c|}
\hline $\begin{array}{c}\text { Day of } \\
\text { analysis }\end{array}$ & Linear regression & $\begin{array}{l}\text { Determination coef- } \\
\text { ficient }\left(\mathrm{r}^{2}\right)\end{array}$ & Volunteer / session & $\begin{array}{l}\text { Area under the peak } \\
(\mathrm{x})\end{array}$ \\
\hline 1 & $y=3.10^{-8} x-4.10^{-5}$ & 0.9974 & $\begin{array}{c}\text { P4 / } 1 \text { initial } \\
\text { P4 / } 1 \text { final } \\
\text { P4 / } 2 \text { initial } \\
\text { P4 / } 2 \text { final } \\
\text { P4 / } 3 \text { initial } \\
\text { P4 / } 3 \text { final } \\
\text { P5 / } 1 \text { initial } \\
\text { P5 / } 1 \text { final } \\
\text { P5 / } 2 \text { initial } \\
\text { P5 / } 2 \text { final }\end{array}$ & $\begin{array}{c}3,576.0 \\
20,223.8 \\
2,332.8 \\
2,480.0 \\
4,931.2 \\
6,680.0 \\
34,129.6 \\
43,718.4 \\
7,603.2 \\
7,740.8 \\
\end{array}$ \\
\hline 2 & $y=2.10^{-8} x+2.10^{-5}$ & 0.9990 & $\begin{array}{l}\text { P5 / } 3 \text { initial } \\
\text { P5 / } 3 \text { final }\end{array}$ & $\begin{array}{c}3,803.2 \\
23,950.4\end{array}$ \\
\hline 3 & $y=2.10^{-8} x+6.10^{-6}$ & 0.9913 & $\begin{array}{l}\text { P1 / } 1 \text { initial } \\
\text { P1 / } 1 \text { final } \\
\text { P1 / } 2 \text { initial } \\
\text { P1 / } 2 \text { final } \\
\text { P1 / } 3 \text { initial } \\
\text { P1 / } 3 \text { final }\end{array}$ & $\begin{array}{l}5,817.6 \\
6,905.6 \\
6,240.0 \\
6,649.6 \\
1,292.8 \\
4,763.2 \\
\end{array}$ \\
\hline 4 & $y=3.10^{-8} x+8.10^{-5}$ & 0.9954 & $\begin{array}{l}\text { P2 / } 1 \text { initial } \\
\text { P2 / } 1 \text { final } \\
\text { P2 / } 2 \text { initial } \\
\text { P2 / } 2 \text { final } \\
\text { P2 / } 3 \text { initial } \\
\text { P2 / } 3 \text { final }\end{array}$ & $\begin{array}{c}6,428.8 \\
14,163.2 \\
5,017.6 \\
12,294.4 \\
7,878.4 \\
8,601.6 \\
\end{array}$ \\
\hline 5 & $y=3.10^{-8} x+2.10^{-5}$ & 0.9989 & $\begin{array}{c}\text { P3 / } 1 \text { initial } \\
\text { P3 / } 1 \text { final } \\
\text { P3 / } 2 \text { initial } \\
\text { P3 / } 2 \text { final } \\
\text { P3 / } 3 \text { initial } \\
\text { P3 / } 3 \text { final }\end{array}$ & $\begin{array}{c}8,726.4 \\
9,568.1 \\
6,364.8 \\
10,486.4 \\
4,528.8 \\
9,740.8 \\
\end{array}$ \\
\hline 6 & $y=2.10^{-8} x-2.10^{-5}$ & 0.9994 & $\begin{array}{l}\text { V1 } \\
\text { V2 } \\
\text { V3 }\end{array}$ & $\begin{array}{l}2,750.4 \\
1,081.6 \\
1,604.8\end{array}$ \\
\hline
\end{tabular}

$\mathrm{P}=$ volunteer patient; $\mathrm{V}=$ healthy volunteer.

The coefficient of determination $\left(\mathrm{r}^{2}\right)$ of the linear regression of each calibration curve was determined to verify its reliability. Among the coefficients of determination, the lowest value was 0.9913 being, therefore, by the ANVISA and the National Institute of Metrology (INMETRO) requirements (above 0.90) [22]. Table 3 presents the mass of DEHP determined using the linear regression equations showed in Table 2.

The VC shows low homogeneity of data meaning that the cumulative DEHP is not only related to the extracorporeal circuit and the conditions of the procedure and can be attributed to the metabolic condition of the patient. However, in all cases, it was found higher values of DEHP in the blood near to the end of session compared to the beginning.

The amount of DEHP released depends on the blood flow and on the exposure time of the blood to the PVC circuit [23] [24]. Then the DEHP accumulated per patient per session ( $\triangle \mathrm{DEHP})$ was multiplied by the blood flow and by the dialysis period (240 min). The results in $\mathrm{mg}$ (MDEHP) were used to calculate the average mass of DEHP released per patient (MDEHPM) (Table 4). 
Table 3: The concentration of DEHP in the blood of the volunteer patients determined using the data from Table 2.

\begin{tabular}{|c|c|c|c|c|}
\hline $\begin{array}{l}\text { Patient } \\
\text { /session }\end{array}$ & $\begin{array}{c}\text { Concentration of DEHP } \\
(\mu \mathrm{g} / \mathrm{ml}) 15 \text { min after the } \\
\text { session has started }\end{array}$ & $\begin{array}{l}\text { Concentration of DEHP } \\
(\mu \mathrm{g} / \mathrm{ml}) 15 \text { min before the } \\
\text { session has finished }\end{array}$ & $\begin{array}{c}\text { DEHP accumulated } \\
\text { per patient, } \triangle \mathrm{DEHP} \mathrm{m}_{\mathrm{m}} \\
(\mu \mathrm{g} / \mathrm{ml}) \pm \mathrm{SD} \\
\end{array}$ & $\begin{array}{c}\mathrm{VC}(\%) \\
\text { for } \\
\Delta \mathrm{DEHP}_{\mathrm{m}}\end{array}$ \\
\hline $\begin{array}{l}\mathrm{P} 1 / 1 \\
\mathrm{P} 1 / 2 \\
\mathrm{P} 1 / 3\end{array}$ & $\begin{array}{l}0.122^{*} \\
0.131^{*} \\
0.032^{*}\end{array}$ & $\begin{array}{l}0.144^{*} \\
0.139^{*} \\
0.101^{*}\end{array}$ & $0.033 \pm 0.030$ & 96,83 \\
\hline $\begin{array}{l}\mathrm{P} 2 / 1 \\
\mathrm{P} 2 / 2 \\
\mathrm{P} 2 / 3\end{array}$ & $\begin{array}{l}0.273 \\
0.231 \\
0.316 \\
\end{array}$ & $\begin{array}{l}0.505 \\
0.449 \\
0.338\end{array}$ & $0.157 \pm 0.120$ & 74.63 \\
\hline $\begin{array}{l}\mathrm{P} 3 / 1 \\
\mathrm{P} 3 / 2 \\
\mathrm{P} 3 / 3 \\
\end{array}$ & $\begin{array}{l}0.242 \\
0.171^{*} \\
0.101^{*}\end{array}$ & $\begin{array}{l}0.267 \\
0.296 \\
0.202 \\
\end{array}$ & $0.083 \pm 0.252$ & 62.40 \\
\hline $\begin{array}{l}\mathrm{P} 4 / 1 \\
\mathrm{P} 4 / 2 \\
\mathrm{P} 4 / 3\end{array}$ & $\begin{array}{l}0.103^{*} \\
0.029^{*} \\
0.108^{*}\end{array}$ & $\begin{array}{l}0.567 \\
0.034^{*} \\
0.161^{*}\end{array}$ & $0.174 \pm 0.231$ & 144,99 \\
\hline $\begin{array}{l}\text { P5 / } 1 \\
\text { P5 / } 2 \\
\text { P5 / } 3\end{array}$ & $\begin{array}{l}0.984 \\
0.188^{*} \\
0.096^{*}\end{array}$ & $\begin{array}{c}1.272 \\
0.192^{*} \\
0.499\end{array}$ & $0.232 \pm 0.205$ & 88.64 \\
\hline
\end{tabular}

Samples with ${ }^{*}$ indicate concentration below the limit of quantification $(<0.197 \mu \mathrm{g} / \mathrm{ml}) ; \mathrm{SD}=$ Standard Desviation; $\mathrm{VC}=$ Variation Coeficient.

Applying the non-parametric Kruskal-Wallis test to the MDEPH values, it is concluded that there is not enough evidence to claim that the medians are different from each other, at the 0.05 significance level inferring, therefore, that at least one pair of medians is unequal. However, it is possible to compare the patients each other and to compare the patients with the healthy volunteers.

Table 4: The average mass of DEHP in the blood of the volunteer patients.

\begin{tabular}{|c|c|c|c|c|c|}
\hline $\begin{array}{l}\text { Patient/ } \\
\text { Session }\end{array}$ & $\begin{array}{l}\triangle \mathrm{DEHP} \\
(\mu \mathrm{g} / \mathrm{ml})\end{array}$ & $\begin{array}{l}\text { Blood flow } \\
(\mathrm{ml} / \mathrm{min})\end{array}$ & $\begin{array}{l}\triangle \text { DEHP } \times \text { flow } \\
(\mu \mathrm{g} / \mathrm{min})\end{array}$ & $\begin{array}{l}\text { MDEHP per } \\
\text { session (mg) }\end{array}$ & $\begin{array}{c}\operatorname{MDEHP}_{\mathrm{M}}(\mathrm{mg}) \pm \\
\mathrm{SD}\end{array}$ \\
\hline $\mathrm{P} 1 / 1$ & 0.022 & \multirow{3}{*}{300} & 6.60 & - & \multirow{3}{*}{ - } \\
\hline $\mathrm{P} 1 / 2$ & 0.008 & & 2.40 & - & \\
\hline $\mathrm{P} 1 / 3$ & 0.069 & & 20.70 & - & \\
\hline $\mathrm{P} 2 / 1$ & 0.232 & \multirow{3}{*}{300} & 69.60 & 16.70 & \multirow{3}{*}{$11.32 \pm 8.45$} \\
\hline $\mathrm{P} 2 / 2$ & 0.218 & & 65.40 & 15.69 & \\
\hline $\mathrm{P} 2 / 3$ & 0.022 & & 6.60 & 1.58 & \\
\hline $\mathrm{P} 3 / 1$ & 0.025 & \multirow{3}{*}{300} & 7.50 & 1.80 & \multirow{3}{*}{-} \\
\hline $\mathrm{P} 3 / 2$ & 0.125 & & 37.50 & - & \\
\hline $\mathrm{P} 3 / 3$ & 0.053 & & 15.90 & - & \\
\hline $\mathrm{P} 4 / 1$ & 0.464 & \multirow{3}{*}{350} & 162.40 & - & \multirow{3}{*}{-} \\
\hline $\mathrm{P} 4 / 2$ & 0.005 & & 1.75 & - & \\
\hline $\mathrm{P} 4 / 3$ & 0.523 & & 183.05 & - & \\
\hline $\mathrm{P} 5 / 1$ & 0.287 & \multirow{3}{*}{350} & 100.45 & 24.11 & \multirow{3}{*}{-} \\
\hline $\mathrm{P} 5 / 2$ & 0.004 & & 1.40 & - & \\
\hline $\mathrm{P} 5 / 3$ & 0.403 & & 141.05 & - & \\
\hline
\end{tabular}

In Table 4, the MDEHP and the $\mathrm{MDEHP}_{\mathrm{M}}$ were not determined for the samples indicated in Table 3 having concentrations below the limit of quantification $(0.197 \mu \mathrm{g} / \mathrm{ml})$. However, the $\Delta \mathrm{DEHP}(\mu \mathrm{g} / \mathrm{ml})$ and the $\triangle$ DEHP $\mathrm{x}$ flow $(\mu \mathrm{g} / \mathrm{min})$ can be used to conclude about the DEHP released in the blood of the patients.

Table 5 shows the body weight of each patient and the average mass of DEHP released per $\mathrm{kg}$ of body weight (MDEHPMK). Table 6 displays the mass of DEHP detected in the blood of the healthy volunteers per $\mathrm{kg}$ of body weight for comparison with the volunteer patients. 
Table 5: The average mass of DEHP released in the blood of the volunteer patients per $\mathrm{kg}$ of body weight.

\begin{tabular}{c|c|c|c}
\hline Patient & $\begin{array}{c}\mathrm{MDEHP}_{\mathrm{M}} \\
(\mathrm{mg})\end{array}$ & $\begin{array}{c}\text { Body weight } \\
(\mathrm{kg})\end{array}$ & $\begin{array}{c}\mathrm{MDEHP}_{\mathrm{M} / \mathrm{K}} \\
(\mathrm{mg} / \mathrm{kg})\end{array}$ \\
\hline P2 & $11.32 \pm 8.45$ & $60.0 \pm 0.05$ & $0.19 \pm 0.14$ \\
\hline P3 & $1,80 \pm 0,00$ & $71.5 \pm 0.05$ & $0.07 \pm 0.05$ \\
\hline P4 & $27.78 \pm 23.81$ & $70.0 \pm 0.05$ & $0.39 \pm 0.34$ \\
\hline P5 & $19.43 \pm 17.24$ & $75.5 \pm 0.05$ & $0.26 \pm 0.23$ \\
\hline
\end{tabular}

Table 6: Mass of DEHP detected in the healthy volunteer blood per kg of body weight.

\begin{tabular}{c|c|c|c|c}
\hline Volunteer & $\begin{array}{c}\text { DEHP } \\
(\mu \mathrm{g} / \mathrm{ml})\end{array}$ & $\begin{array}{c}\text { MDEHP }_{\mathrm{M}} \\
(\mu \mathrm{g})\end{array}$ & $\begin{array}{c}\text { Body weight } \\
(\mathrm{kg})\end{array}$ & DEHP $_{\mathrm{M}}(\mu \mathrm{g} / \mathrm{kg})$ \\
\hline $\mathrm{V} 1$ & 0.035 & 0.35 & $60.20 \pm 0.05$ & $0.006 \pm 0,001$ \\
\hline $\mathrm{V} 2$ & 0.002 & 0.02 & $54.50 \pm 0.05$ & $0.000 \pm 0.001$ \\
\hline $\mathrm{V} 3$ & 0.012 & 0.12 & $56.40 \pm 0.05$ & $0.002 \pm 0.001$ \\
\hline
\end{tabular}

From Table 5 and Table 6 one can see that the mass of DEHP in the blood of the healthy volunteers is in the order of $\mu \mathrm{g} / \mathrm{kg}$ while for the patients is in the order of $\mathrm{mg} / \mathrm{kg}$. The average DEHP for the healthy volunteer was $0.003 \pm 0.002 \mu \mathrm{g} / \mathrm{kg}$, and for patients volunteer was $0.19 \pm 0.16 \mathrm{mg} / \mathrm{kg}$, much higher than the first one. Although the reduced number of volunteer prevents the validation of the method, it can be used to verify its feasibility as well as the right procedure to prepare samples from the blood to analyze in HPLC equipment.

\section{DISCUSSION}

Analyzing the hemodialysis sessions 1, 2 and 3 of each patient one can see the change in the average amount of DEHP released, also observed in the literature that records values between $44.3 \mathrm{mg}$ and $197.1 \mathrm{mg}$ in a single dialysis session [23] [24]. The variation observed can be linked to the lipophilic nature of the blood of each patient, the time of collection, or to his hepatic function because DEHP is metabolized in the liver [12] [26].

Regarding the reuse of the extracorporeal circuit, it was expected that the amount of DEHP released increased with the number of reuses. Because the DEHP is not strongly bonded to the PVC [18] [27], it can easily release into the blood, and the more degraded is the polymer more plasticizer is released. However, the $\triangle \mathrm{DEHP}$ of the P3 who reused the circuit thirteen times was lower than that of the P4 with four reuse. One possible reason is the heterogeneity of the polymeric material. As the plasticizer is added to the polymeric raw material before or during the extrusion process for manufacturing the circuit, an inhomogeneous mixture of DEHP plasticizer in the PVC may occur creating sites with high concentrations of the plasticizer [28]. These sites, when in contact with the blood can release a high amount of DEHP [29] instantly that may explain the discrepancy between values in the same patient.

The P5 started the sessions with high concentrations of DEHP in the blood. The circuit was reused fifteen times in this patient, and it was, therefore, in a high level of degradation, and even though had received the higher amount of heparin, the $\triangle$ DEHPm in the P5 blood was the highest $(0.232 \pm 0.205 \mathrm{mg} / \mathrm{kg})$. Heparin is hepatic lipase activator [30] and, consequently, the patients that continuously receive it have an increasing conversion rate of DEHP into its metabolic, resulting in a reduced amount of DEHP detected in the plasma. Therefore, even taking 8,000 UI of heparin, the patient 5 did not metabolize the DEHP as expected, because having constant contact with the contaminant the body's ability to metabolize it can be affected [26].

The heparin effect can also be seen in the P2 that, having the same flow of the patients P1 and P3, presented higher concentration of DEHP $(0.19 \pm 0.14 \mathrm{mg} / \mathrm{kg})$, especially when compared to P3 $(0.07 \pm 0.05$ $\mathrm{mg} / \mathrm{kg}$ ) who had taken 6,000 UI of heparin and thirteen reuses.

Analyzing the blood flow, the patients P4 and P5, which had a higher flow than the other, had a higher value of DEHP released despite receiving a greater amount of heparin. The higher doses of heparin are justified by the local shear stresses between the blood and the PVC surface that activate the platelets and increase the probability of thrombus formation. In the extracorporeal circuits, the tubes with an average diame- 
ter of $3 \mathrm{~mm}$ suffer shear stresses up to 63 dynes $/ \mathrm{cm}^{2}$. The stresses that activate the platelets occur between 60 and 80 dynes $/ \mathrm{cm}^{2}$ [31]. The higher flow rate also makes the volume of blood transit more times in the circuit increasing the amount of DEHP released.

Data from Table 6 show that, although DEHP is not absent in the blood of the healthy volunteers due to their exposure to this compound normally found in the environment, the concentrations are very low compared to those in the blood of the volunteer patients. For the healthy volunteers, it was found an average value of $0.003 \pm 0.002 \mu \mathrm{g} / \mathrm{kg}$, and a much higher value $(0.19 \pm 0.21 \mathrm{mg} / \mathrm{kg})$ was found in the blood of the volunteer patients.

A higher value of the concentration of DEHP in the blood of healthy volunteers $(0.62 \pm 0.12 \mu \mathrm{g} / \mathrm{ml})$ was detected in the study conducted by FAOUZI et al. [20] The lower average concentration of $0.016 \pm 0.017$ $\mu \mathrm{g} / \mathrm{ml}$ found in the present study can be explained by the fact that it strongly depends on the environment where the volunteer is in contact daily. Studies that monitored DEHP in indoor air reported about $0.11 \mu \mathrm{g} / \mathrm{m}^{3}$ in Japan and about $0.09 \mu \mathrm{g} / \mathrm{m}^{3}$ in the USA [32].

Considering the P2 with an average of $11.32 \pm 8.45 \mathrm{mg}$ of DEHP in three sessions, the amount of DEHP in a year of 52 weeks would be about $0.59 \mathrm{~g}$. This value is still very low according to the literature. FAOUZI et al. [20], reported the amount of $11,74 \mathrm{~g}$, considering sessions of four hours, three times a week, and using HPLC as detection instrument. Also, the same authors found the maximum concentration of DEHP in the blood of 21 hemodialysis patients of $4.2 \mu \mathrm{g} / \mathrm{ml}$ against $0.523 \mu \mathrm{g} / \mathrm{ml}$ found in this study.

Either way, based on the daily limit of DEHP defined by the RDC 35, 2014 ANVISA as $0.025 \mathrm{mg} / \mathrm{kg}$ of body mass, all patients volunteer had average values substantially higher than the maximum set by the ANVISA.

\section{CONCLUSIONS}

Despite the limited number of patients, the aim of this study was to demonstrate the feasibility of the HPLC to quantify the DEHP in the blood of hemodialyzed patients presenting the steps to prepare the plasma samples and to handle the results from the HPLC. The findings indicate that patients undergoing hemodialysis using extracorporeal circuit manufactured in PVC are exposed to high doses of DEHP.

\section{BIBLIOGRAPHY}

[1] BASTOS, M.G., BREGMAN, R., KIRSZTAJN, G.M., "Chronic kidney diseases: common and harmful, but also preventable and treatable", Revista da Associação Médica Brasileira; v. 56, n. 2, pp. 248-253, 2010.

[2] BEZERRA K.V., SANTOS J.L.F., "O cotidiano de pessoas com insuficiência renal crônica em tratamento hemodialítico", Revista Latino-Americana de Enfermagem; v. 16, n. 4, pp. 686-691, 2008.

[3] NASCIMENTO, C.D., MARQUES, I.R., "Intervenções de enfermagem nas complicações mais frequentes durante a sessão de hemodiálise: revisão da literatura", Revista Brasileira de Enfermagem; v. 58, n. 6, pp. 719-722, 2005.

[4] LARA, E.A., SARGUIS, L.M.M., "O Paciente renal Crônico e sua Relação com o Trabalho", Cogitare Enfermagem; v. 9, n. 2, pp. 99-105, 2004.

[5] UPADHYAY A., SOSA M.A., JABER B.J., "Single use versus reusable dialyzers: the known unknowns", Clinical Journal of the American Society of Nephrology; v. 2, pp. 1079-1086, 2007.

[6] TWARDOWSKI Z.J., "Dialyzer reuse - part II: advantages and disadvantages", Seminar in Dialysis; v. 19, pp. 217-219, 2006.

[7] LACSON E.J., LAZARUS J.M., “Dialyzers Best Practice: Single Use or Reuse?” Seminar in Dialysis; v. 19, pp. 120-128, 2006.

[8] ESTEVES A.A., BORGES S.V., ABRANTES S., et al., "Validação em laboratório de método analítico para determinação do teor de adipato e ftalato de di-(2 - etil- hexila) utilizados como plastificantes em filmes flexíveis de PVC", Química Nova; v. 30, n. 1, pp. 219-233, 2007.

[9] VINHAS, G.M., SOUTO-MAIOR, R.M., LAPA, C.M., et al., "Degradation studies on plasticized PVC films submitted to gamma radiation"; Materials Research; v. 6, n. 4, pp. 497-500, 2003.

[10] BOURDEAUX, D., SAUTOU-MIRANDA, V., BAGEL-BOITHIAS, S., et al., "Analysis by liquid chromatography and infrared spectrometry of di (2- ethylhexyl) phthalate released by multilayer infusion tubing", Journal of Pharmaceutical and Biomedical Analysis; v. 35, pp. 57-64, 2004. 
[11] MONTEIRO, M., GOTARDO, M.A., "Ftalato de di-(2-etilexila) (DEHP) em bolsas de PVC para soluções parenterais de grandes volumes", Revista de Ciências Farmacêuticas Básica e Aplicada; v. 26, n. 1, pp. 9-18, 2005.

[12] CALAFAT, A.M., NEEDHAM, L.L., SILVA, M.J., et al., "Exposure to di - (2 - ethylhexyl) phthalate among premature neonates in a neonatal intensive care unit", Pediatrics; v. 113, n. 5, pp. 429-434, 2004.

[13] BERNARD, B., DÉCAUDIN, M., LECOEUR, D., et al., "Analytical methods for the determination of DEHP plasticizer alternatives present in medical devices: A review”, Talanta; v. 129, pp. 39-54, 2014.

[14] RONCO, C., GHEZZI, P.M., BRENDOLAN, A., et al., "The hemodialysis system: basic mechanisms of water and solute transport in extracorporeal renal replacement therapies", Nephrology Dialysis Transplantation; v. 13, Suppl. 6, pp. 3-9, 1998.

[15] HAISHIMA, Y., MATSUDA, R., HAYASHI, Y., et al., "Risk assessment of di(2-ethylhexyl) phthalate released from PVC blood circuits during hemodialysis and pump-oxygenation therapy", International Journal of Pharmacology; v. 274, pp. 119-129, 2004.

[16] European Commission. Opinion on medical devices containing DEHP plasticized PVC; neonates and other groups possibly at risk from DEHP toxicity.

http://ec.europa.eu/health/archive/ph_risk/committees/scmp/documents/out43_en.pdf, 2002. Acessado em 08 de setembro de 2014.

[17] OLUJIMI, O.O., FATOKI, O.S., ODENDAAL, J.P., et al., "Endocrine disrupting chemicals (phenol and phthalates) in the South African environment: a need for more monitoring", Water SA; v. 36, n. 5, pp. 671682,2010

[18] DIGANGi, J., SCHETTLER, T., COBBING, M., et al., AGGREGATE EXPOSURES TO PHTHALATES IN HUMANS. http://www.fda.gov/ohrms/dockets/dailys/02/Dec02/120502/02d-0325c000018-02-vol1.pdf, 2002. Acessado em 15 de março de 2014.

[19] CHAUDHARY, A.K., ANKUSHRAO, W.S., YADAV, S., et al., "Validated reverse phase HPLC method for the determination of DEHP content in reconstituting diluents and in reconstituted solutions of imipenem and cilastatin for injection”, Journal of Chemistry; v. 7, n. 2, pp. 501-513, 2010.

[20] FAOUZI, M.A., DINE, T., GRESSIER, B., et al., "Exposure of hemodialysis patients to di-2ethylhexyl phthalate", International Journal of Pharmacology; v. 180, pp. 113-121, 1999.

[21] AUBUCHON, J.P., ESTEP, T.N., DAVEY, R.J., "The effect of the plasticizer di-2-ethylhexyl phthalate on the survival of stored RBCs", Blood; v. 2, pp. 448-452, 2015.

[22] RIBANI, M., BOTTOLI, C.B.G., COLLINS, C.H., et al., "Validação em Métodos Cromatográfico e Eletroforéticos", Química Nova; v. 27, n. 5, pp. 771-780, 2004.

[23] DINE, T., LUYCKX, M., GRESSIER, B., et al., "A pharmacokinetic interpretation of increasing concentrations of DEHP in haemodialysed patients", Medical Engineering \& Physics; v. 22, n. 3, pp. 157-165, 2000.

[24] POLLACK, G.M., BUCHANAN, J.F., SLAUGHTER, R.L., et al., "Circulating concentrations of di(2ethylhexyl) phthalate and its de-sterilised phthalic acid products following plasticizer exposure in patients receiving hemodialysis", Toxicology and Applied Pharmacology; v. 79, n. 2, pp. 257-267, 1985.

[25] KAMBIA, K., DINE, T., AZAR, R., et al., "Comparative study of the leachability of di(2-ethylhexyl) phthalate and tri(2-tehylhexyl)trimellitate from hemodialysis tubing", International Journal of Pharmacology; v. 229, pp. 139-146, 2001.

[26] LEWIS, L.M., FLECHTNER, T.W., KERKAY, J., et al., "Bis(2-ethylhexyl)phthalate concentrations in the serum of hemodialysis patients", Clinical Chemistry; v. 24, n. 5, pp. 741-746, 1978.

[27] VAN VLIET E.D.S., REITANO, E.M., CHHABRA, J.S., et al., "A review of alternatives to di (2ethylhexyl) phthalate-containing medical devices in the neonatal intensive care unit", Journal of Perinatology; v. 31, n. 8, pp. 551-560, 2011.

[28] SCHWARTZ, G.R., PALUCH, M., ALEGRÍA, A., et al., "High pressure dynamics of polymer/plasticizer mixtures", Journal of Chemical Physics; v. 131, pp. 5-9, 2009.

[29] VEIGA, M., BOHRER, D., NASCIMENTO, P.C., et al., "Migration of Phthalate-based Plasticizers from PVC and non-PVC Containers and Medical Devices", Journal of the Brazilian Chemical Society; v. 23, n. 1, pp. 72-77, 2012.

[30] US Department of Health and Human Services. Toxicological profile for di (2-ethylhexyl) phthalate. 
http://www.atsdr.cdc.gov/toxprofiles/tp9.pdf, 2002. Acessado em 23 de maio de 2014.

[31] SPIJKER, H.T., GRAAF, R., BOONSTRA, P.W., et al., "On the influence of flow conditions and wettability on blood material interactions", Biomaterials; v. 24, pp. 4717-4727, 2003.

[32] FONG, J-P., LEE, F-J., LU, I-S., et al., "Estimating the contribution of inhalation exposure to di-2ethylhexyl phthalate (DEPH) for PVC production workers, using personal air sampling and urinary metabolite monitoring", International Journal of Hygiene and Environmental Health, n. 217, pp.102-109, 2014. 